\title{
ETYKA NA RYNKU USEUG DORADZTWA I POŚREDNICTWA FINANSOWEGO
}

\begin{abstract}
Streszczenie: Celem niniejszego rozdziatu jest ustalenie znaczenia postepowania instytucji doradztwa i pośrednictwa finansowego zgodnie z zasadami etyki na rynku ustug finansowych. Problem badawczy dotyczy postępowania zgodnie z zasadami etyki na rynku doradztwa i pośrednictwa finansowego. Do osiagnięcia postawionego celu zastosowano gtównie metodę analizy literatury przedmiotu, danych prezentowanych przez organizacje doradców finansowych oraz analize aktów prawnych. Opracowanie składa się z trzech części: w pierwszej skupiono uwagę na znaczeniu etyki na rynku uslug finansowych, $w$ drugiej przedstawiono instytucje doradztwa i pośrednictwa finansowego na rynku ustug finansowych ( $z$ wyłaczeniem banków oraz ubezpieczycieli), natomiast $w$ części trzeciej zaprezentowano kodeksy etyki oraz instytucje je stosujące na rynku doradztwa i pośrednictwa finansowego. W wyniku przeprowadzonych analiz zauważono, że postępowanie zgodnie z zasadami etyki na rynku ustug $i$ doradztwa finansowego jest niezbędnym warunkiem dalszego rozwoju i stabilności tego rynku.
\end{abstract}

Stowa kluczowe: doradztwo finansowe, pośrednictwo finansowe, kodeks etyki.

\section{WSTĘP}

We współczesnej gospodarce wyraźnie widoczne jest występowanie ekonomicznej motywacji zachowań etycznych. Wynika to z tego, że bycie nieetycznym jest kosztowne a etyczne postępowanie wręcz generuje dodatkowe zyski ${ }^{1}$.

Rynek doradztwa finansowego w Polsce to młody segment rynku, jednak już znacznie rozbudowany. Zawód doradcy finansowego w Polsce jest często postrzegany wyłącznie jako pośrednik finansowy. Pojawiają się jednak coraz częściej opinie wskazujące na stopniową zmianę postrzegania zawodu doradcy finansowego jako doradcy budującego długoterminowe relacje z klientami. Rynek doradztwa finansowego w Polsce jest zdecydowanie rozproszony, co utrudnia dokładne określenie liczby firm świadczących usługi doradztwa finansowego. Wynika to między innymi z rozdrobnienia i rozproszenia rynku. Stąd pomocne okazują się dane gromadzone przez organizacje zrzeszające doradców finansowych. W Polsce funkcjonuje Związek Firm Doradztwa Finansowego

\footnotetext{
* Dr Joanna Stawska, Wydział Ekonomiczno-Socjologiczny, Uniwersytet Łódzki.

${ }^{1}$ A. Strzelecki, Moda na etykę. Wspótczesna refleksja etyczna w biznesie i fenomen jej popularności, „Studia i Materiały” 2005, nr 1, s. 24-25.
} 
(ZFDF) jako główny organ zrzeszający firmy o tym profilu działalności². Do ZFDF należy obecnie dziesięć największych firm zajmujących się doradztwem i pośrednictwem finansowym: Aspiro, Bankier, Doradcy 24 SA, Expander Advisors, FinPack, Gold Finance, Home Broker, Idea Expert, Notus Doradcy Finansowi, Open Finance ${ }^{3}$. Bankier.pl oraz „Wprost” opracowały raport pt. Rynek doradztwa finansowego w Polsce 2012, nad którym patronat objął Związek Firm Doradztwa Finansowego. W badaniu ankietowym uzyskano 2281 wypełnionych ankiet. Badanie to zostało przeprowadzone w okresie tzw. drugiej fazy kryzysu finansowego (kryzys długu finansów publicznych), co z pewnością miało wpływ na udzielane odpowiedzi. Było to widoczne chociażby w słabym zaufaniu klientów do instytucji finansowych i banków. Według tego raportu $14 \%$ ankietowanych nie darzyło żadnym zaufaniem banków, firm ubezpieczeniowych czy Towarzystw Emerytalnych, natomiast $72 \%$ respondentów miało ograniczone zaufanie do instytucji finansowych, a jedynie $13 \%$ pełne zaufanie ${ }^{4}$.

Istotna dla firm świadczących usługi doradztwa finansowego powinna być również informacja wynikająca z raportu Rynek doradztwa finansowego w Polsce 2012 , która wskazuje na to, że dla $67 \%$ respondentów ważne są zarówno zysk i bezpieczeństwo , dla $16 \%$ ważniejszy jest zysk od bezpieczeństwa, a $18 \%$ badanych bezpieczeństwo stawia na pierwszym miejscu. Te informacje powinny być ważne w kontekście współpracy firm doradztwa finansowego z klientami. Przedsiębiorstwa takie powinny funkcjonować w oparciu o przyjęte zasady etyki i odpowiedzialnej współpracy, powinny dbać o budowanie odpowiednich relacji z klientami, koncentrując się na poziomie zaufania klientów do tych firm ${ }^{5}$.

Stąd celem niniejszego opracowania jest ustalenie znaczenia postępowania instytucji doradztwa i pośrednictwa finansowego zgodnie z zasadami etyki na rynku usług finansowych. W rozdziale wykorzystano analizę dostępnej literatury przedmiotu, danych prezentowanych przez organizacje doradców finansowych, Związek Firm Doradztwa Finansowego i analizę aktów prawnych.

\section{ZNACZENIE ETYKI NA RYNKU USEUG FINANSOWYCH}

Etyka staje się coraz ważniejszym elementem działalności gospodarczej. Według R. E. Freemana przestrzeganie wysokich standardów etycznych w przedsiębiorstwie jest jednym ze źródeł jego przewagi konkurencyjnej,

\footnotetext{
${ }^{2}$ Rynek doradztwa finansowego $w$ Polsce 2012, Raport Bankier.pl i „Wprost”, http://www.bankier.pl/static/att/90000/2492942_RaportRynekDoradztwaFinansowegowPolsce2012.pdf, s. 10-14 [dostęp: 12.02.2016].

${ }^{3}$ Związek Firm Doradztwa Finansowego, http://www.zwiazek-doradcow.org/index.php/czlonkowie-zfdf [dostęp 18.02.2016].

${ }^{4}$ Rynek doradztwa...

${ }^{5}$ Ibidem, s. 22.
} 
zwłaszcza w niepewnym otoczeniu (np. w dobie kryzysów finansowych) ${ }^{6}$. W ekonomii kodeksy etyczne definiuje się jako dokumenty, drogowskazy moralne, zawierające określone zasady i reguły postępowania ${ }^{7}$. Inaczej ujmując, etyka biznesu jest zastosowaniem ogólnych zasad etycznych do problemów związanych z biznesem ${ }^{8}$. Uczestnicy życia gospodarczego zauważają, że etyczne postępowanie staje się podstawą efektywnego funkcjonowania na rynku. Stąd coraz większe zainteresowanie środowiska biznesu kodeksami etycznymi. Kodeksy etyczne to zbiory norm postępowania i wzorów zachowania podmiotów, które działają w sferze biznesu'. Kodeksy etyczne stanowią element infrastruktury etycznej przedsiębiorstw z różnych branż ze wskazaniem sektora finansowego, gdzie kodeksy etyczne powinny być szczególnie obecne ${ }^{10}$. Za wzór dla kodeksów etycznych uważa się uchwaloną w 2002 r. w USA ustawę Sarbanes-Oxley Act, która nakładała obowiązek wdrażania procedur przejrzystego i etycznego postępowania przez spółki giełdowe ${ }^{11}$.

Kodeksy etyczne mogą być oparte na międzynarodowych standardach postępowania $\mathrm{w}$ sferze działalności gospodarczej lub mogą określać etykę zawodową pewnej grupy branżowej. W tym miejscu warto wspomnieć o Manifeście z Davos, który opracowano w 1973 r. podczas Europejskiego Sympozjum Zarządzania. W dokumencie tym podkreślono rolę odpowiedzialności, szczególnie kadry kierowniczej, wobec interesariuszy i społeczeństwa oraz stwierdzono, że rola biznesu nie polega tylko na przynoszeniu zysku ${ }^{12}$. Kolejny dokument zawierający zbiór reguł postępowania w obszarze działalności gospodarczej to Globalne Zasady Sullivana (The Global Sullivan Principles of Social Responsibility) ogłoszone na zgromadzeniu ONZ w 1999 r. Zasady te promują znaczenie społecznej odpowiedzialności biznesu, wspierają ideę zrównoważonego rozwoju oraz podkreślają prawa i godność pracowników ${ }^{13}$. Wśród międzynarodowych inicjatyw postępowania zgodnie z zasadami etycznymi w środowisku gospodarczym są również tzw. Zasady Okragłego Stołu z Caux (Caux Round Table Prin-

${ }^{6}$ E. Freeman, Strategic Management:A Stakeholder Approach, Pitman, Boston 1984.

${ }^{7}$ J. Klimek, Etyka biznesu, Teoretyczne założenia, praktyka zastosowań, Difin, Warszawa 2014, s. 213.

${ }^{8}$ W. Gasparski, Europejskie standardy etyki biznesu, http://www.ipsir.uw.edu.pl/UserFiles/ File/Katedra_Socjologii_Norm/TEKSTY/WGasparskiEuropStandEtykiBiznesu.pdf [dostęp 22.02.2016].

${ }^{9}$ W. Gasparski, Wyktady z etyki biznesu, WSPiZ, Warszawa 2007, s. 276.

${ }^{10} \mathrm{M}$. Wiśniewska, Kodeks dobrej praktyki bankowej jako zbiór norm etycznych i ważny element kultury bankowego środowiska zawodowego. Etyka biznesu i etyka zawodowa, „Annales. Etyka w Życiu Gospodarczym” 2003, vol. 6.

${ }^{11}$ C. Lipiński, Etyka w bankowości - dylematy pracownika bankowego, „Annales. Etyka w Życiu Gospodarczym" 2008, vol. 11, nr 2, s. 88.

${ }^{12}$ H. Steinmann, G. Schreyogg, Zarzadzanie: podstawy kierowania przedsiębiorstwem. Koncepcje, funkcje, przykłady, Oficyna Wydawnicza Politechniki Wrocławskiej, Wrocław 2001, s. $78-80$.

${ }^{13}$ The Global Sullivan Principles of Social Responsibility, http://www.thesullivanfoun-dation.org/ [dostęp: 19.02.2016]. 
ciples for Business) powstałe w 1986 r. Oparte na japońskiej koncepcji życia i pracy dla wspólnego dobra w taki sposób, by współpraca i wzajemna pomyślność wspólistniały z uczciwą konkurencją. Wśród zasad ogólnych w dokumencie wymienia się między innymi odpowiedzialne prowadzenie działalności gospodarczej, rozumiane poprzez dostarczanie na rynek produktów i usług, których jakość odpowiada ich cenie ${ }^{14}$. Warto jeszcze wspomnieć o tzw. 10 zasadach Global Compact, które skoncentrowane są na przestrzeganiu praw człowieka, standardów pracy, przeciwdziałaniu korupcji czy promowaniu odpowiedzialności ekologicznej. Global Compact to międzynarodowa inicjatywa, która rekomenduje przestrzeganie kodeksu postępowania w świecie biznesu ${ }^{15}$.

Wśród kodeksów etycznych o charakterze ogólnym, adresowanych do wszystkich przedstawicieli środowiska sfery gospodarczej, znajduje się Kodeks etyki $w$ działalności gospodarczej, który został opracowany przez Krajową Izbę Gospodarczą w 1994 r. $^{16}$

Jednym z elementów, na podstawie, którego można odróżnić prawdziwego doradcę finansowego od podmiotu tylko tak się nazywającego jest wypełnianie przez daną jednostkę zasad 4E (Ethics, Education, Examination, Experience). Twórcą tych zasad jest CFP - Certified Financial Planner Board of Standards, która powstała w $1985 \mathrm{r}$. w Waszyngtonie. Celem tej światowej organizacji jest wprowadzanie i rozwijanie określonych standardów i zasad jako oznak najwyższej jakości w planowaniu finansowym. Organizacja ta skupia się na rozwijaniu etycznych zachowań, kompetencji oraz standardów praktycznego działania wśród doradców finansowych. Istotne znaczenie etyki na rynku usług finansowych jest widoczne chociażby w obowiązku przestrzegania przez doradców finansowych zasady Ethics z 4E, która opiera się na dochowywaniu wierności zasadom etycznym. Doradca w procesie certyfikacji wyraża zgodę na przestrzeganie kodeksu etycznego oraz profesjonalnej odpowiedzialności opracowanych przez radę CFP. Doradcy finansowi zobowiązują się postępować zgodnie z wymaganiami kodeksu i praktyk CFP, wyrażają zgodę na etyczne działania w trakcie proponowania usług finansowych uwzględniając na pierwszym miejscu interes klienta. Postępowanie etyczne doradcy finansowego oznacza, że działa on w sposób zintegrowany, oferując profesjonalne rozwiązania przede wszystkim w nawiązaniu do potrzeb klienta ${ }^{17}$.

Znaczenie etyki na rynku usług finansowych systematycznie wzrasta, co wynika z coraz większej świadomości uczestników życia gospodarczego, że etyczne postępowanie wobec klienta lub kontrahenta zdecydowanie przynosi więcej korzyści niż zachowanie nieetyczne.

\footnotetext{
${ }^{14} \mathrm{http} / / /$ www.cauxroundtable.org/index.cfm?\&menuid=8 [dostęp 19.02.2016].

${ }_{15}^{15} \mathrm{http} / / /$ www.globalcompact.org.pl/pol/Global-Compact/10-Zasad-GC [dostęp 19.02.2016].

${ }^{16}$ I. D. Czechowska, Kodyfikacja standardów etycznych ze szczególnym uwzględnieniem kodeksów etycznych banków, „Bezpieczny Bank” 2015, nr 1(58), s. 102.

${ }^{17} \mathrm{~K}$. Waliszewski, Wspótpraca banków i doradców finansowych w Polsce - szanse i zagrożenia dla banków i sektora bankowego, „Bezpieczny Bank” 2010, nr 3(42), s. 142.
} 


\section{INSTYTUCJE DORADZTWA I POŚREDNICTWA FINANSOWEGO}

Doradztwo finansowe jest częścią systemu finansowego w Polsce. Jest ono świadczone przez specjalistyczne przedsiębiorstwa, które wspomagają decyzje finansowe gospodarstw domowych na różnych etapach zarząadzania finansami osobistymi (kredytowania, zarządzania zadłużeniem, oszczędzania i inwestowania, ubezpieczeń i zabezpieczenia emerytalnego) ${ }^{18}$. Firma doradztwa finansowego to instytucja zajmująca się usługą pośrednictwa i doradztwa przy zakupie produktów lokacyjnych, oszczędnościowych, inwestycyjnych, ubezpieczeniowych i innych, doradzając jednocześnie klientowi w wyborze struktury aktywów. Doradztwo finansowe obejmuje pomoc klientowi w wyborze najlepszej dla niego oferty dostępnej na rynku w zakresie potrzeb klienta i jego możliwości finansowych. Doradztwo finansowe oparte jest na długofalowych relacjach z klientami. Działania doradców dotyczą oceny sytuacji finansowej, pomocy w podjęciu decyzji finansowych, dopasowania oferty do indywidualnych potrzeb klienta i innych usług ułatwiających aktywne zarządzanie własnymi finansami ${ }^{19}$. Według dyrektywy Unii Europejskiej dotyczącej pośrednictwa finansowego doradca finansowy to niezależny, nie związany z konkretną instytucją finansową profesjonalista. Jego rola polega na przekazywaniu klientom merytorycznej wiedzy na temat planowania ich finansów osobistych oraz ochrona ich majątku ${ }^{20}$. W kontekście ochrony interesu klienta oraz działań na rzecz zadbania o bezpieczeństwo finansowe klienta doradca finansowy świadczy klientowi usługi na jak najwyższym poziomie. Ponadto doradca powinien być niezależny i zobowiązany do udzielania bezstronnych porad pobierając wynagrodzenie wyłącznie od swojego klienta. Zadaniem doradcy finansowego jest informowanie i uświadamianie klienta o jego prawach wynikających z przepisów w zakresie ochrony konsumenta usług finansowych ${ }^{21}$. Zawód doradcy finansowego pojawił się pierwszy raz w Stanach Zjednoczonych w 1976 r., a pierwszą firmą szkolącą i egzaminującą doradców finansowych była Financial Planning Standards Board (FPSB) z siedzibą w Denver. Następnie od 1980 r. FPSB rozpoczęła ekspansję poza granice USA, udzielając licencji na szkolenie, egzaminowanie i sporządzanie osobistych planów finansowych w krajach o zbliżonym systemie finansowym

${ }^{18}$ Ibidem, s. 140.

${ }^{19}$ K. Waliszewski, Nadzór i licencjonowanie doradców finansowych i pośredników kredytowych a stabilność i bezpieczeństwo polskiego systemu bankowego, [w:] A. Janc (red.), Banki i system bankowy w obliczu kryzysów finansowych, , ,Zeszyt Naukowy Uniwersytetu Ekonomicznego w Poznaniu" 2010, nr 155, s. 200.

${ }^{20}$ K. Waliszewski, Wspótpraca..., s. 141.

${ }^{21} \mathrm{~K}$. Waliszewski, Planowanie finansów osobistych (zarzadzanie finansami osobistymi) z udziałem doradców finansowych - znaczenie dla gospodarstw domowych i gospodarki, ,Problemy Zarządzania” 2014, vol. 12, nr 4(48), t. 1: Współczesne wyzwania w bankowości i finansach, s. 212 . 
jak: Wielka Brytania czy Australia. W 1986 r. powołano w Wielkiej Brytanii niezależną instytucję - Instytut Planowania Finansowego - zajmującą się planowaniem finansów osobistych. W Unii Europejskiej przyjęło się, że doradca finansowy powinien przejść specjalistyczne szkolenia i zdać certyfikowany egzamin, a następnie co 2-3 lata zdawać testy sprawdzające jego kwalifikacje ${ }^{22}$.

Pośrednik kredytowy to firma, która pośredniczy między bankiem oraz klientem w celu ustalenia warunków transakcji i podpisania umowy kredytowej. Instytucja taka może współpracować z jednym bankiem lub wieloma, wtedy w tym drugim przypadku mówimy o brokerach kredytowych. W rezultacie pośrednictwo finansowe dotyczy działalności instytucji polegającej na równoważeniu popytu na środki finansowe przez podmioty deficytowe $\mathrm{z}$ ich podażą podmiotów nadwyżkowych ${ }^{23}$.

Doradcy finansowi pełnią istotne funkcje, których wypełnianie wymaga od nich rzetelności oraz postępowania zgodnie z zasadami etyki.

Wśród tych funkcji wymienia się $e^{24}$ :

1) przekazywanie klientowi rzetelnej wiedzy na temat dostępnych usług finansowych;

2) oferowanie klientowi doradztwa i pomocy w rozwiązywaniu problemów finansowych, w tym:

- skoncentrowanie doradcy na potrzebach klienta, a nie produktach,

- przeprowadzanie indywidualnych analiz potrzeb klientów,

- dokonywanie oceny bieżącej sytuacji finansowej klienta,

- stałe monitorowanie sytuacji klienta oraz dostosowywanie do niej instrumentów finansowych,

- tworzenie długotrwałych relacji z klientem,

- prezentowanie różnych rozwiązań finansowych oraz tworzenie planów finansowych (długookresowych),

- informowanie klientów o ryzykach związanych z danymi produktami.

3) pośredniczenie w transakcjach pomiędzy klientem a instytucją finansową, która jest oferentem produktu finansowego;

4) wykonywanie czynności operacyjnych mających na celu sfinalizowanie transakcji, czyli gromadzenie dokumentów dostarczonych przez klientów, pomoc $\mathrm{w}$ wypełnianiu wniosków przez klientów, udzielanie pomocy klientom $\mathrm{w}$ dokonaniu formalności związanych $\mathrm{z}$ ustanowieniem zabezpieczenia hipotecznego.

Rynek doradztwa i pośrednictwa finansowego stanowi istotny element rynku finansowego $\mathrm{w}$ Polsce. W celu podkreślenia znaczenia i skali działalności

${ }^{22}$ K. Waliszewski, Wspótpraca..., s. 141.

${ }^{23}$ K. Waliszewski, Nadzór ..., s. 201.

${ }^{24}$ A. Barembruch, Znaczenie doradztwa kredytowego w sprzedaży kredytów, [w:] E. Gostomski, M. Pemczar, B. Lepczyński, A. Barembruch, Pośrednictwo kredytowe w Polsce. Podręcznik dla praktyków, CeDeWu, Warszawa 2006, s. 132. 
przedsiębiorstw pośrednictwa kredytowego przedstawiono wyniki badań GUS, które obejmowały 140 podmiotów prowadzących działalność pośrednictwa kredytowego i udzielających pożyczek ze środków własnych. Przedsiębiorstwa te udzieliły ogółem w 2014 r. 5317 tys. kredytów i pożyczek (o 22,9\% więcej niż w 2013 r.). Z kolei wartość udzielonych kredytów i pożyczek przez badane firmy w 2014 r. wzrosła o $11,7 \%$ (27 $917 \mathrm{mln} \mathrm{zl})$ w porównaniu do $2013 \mathrm{r}^{25}$

Tabela 1. Liczba i wartość udzielonych kredytów i pożyczek z udziałem podmiotów pośrednictwa kredytowego w latach 2013-2014

\begin{tabular}{|l|c|c|c|c|}
\hline \multirow{2}{*}{ Wyszczególnienie } & \multicolumn{2}{c|}{$\begin{array}{c}\text { Liczba kredytów/pożyczek } \\
\text { w tys. szt. }\end{array}$} & \multicolumn{2}{c|}{$\begin{array}{c}\text { Wartość kredytów/pożyczek } \\
\text { w mln zt }\end{array}$} \\
\cline { 2 - 5 } & 2013 & 2014 & 2013 & 2014 \\
\hline \hline Ogółem & 4426 & 5317 & 24996 & 27917 \\
\hline \hline $\begin{array}{l}\text { Przedsiębiorstwa udzielające } \\
\text { pożyczek/kredytów we współpra- } \\
\text { cy z bankami }\end{array}$ & 1593 & 1407 & 19398 & 20336 \\
\hline $\begin{array}{l}\text { Przedsiębiorstwa udzielające } \\
\text { pożyczek ze środków własnych }\end{array}$ & 2696 & 3762 & 5466 & 7332 \\
\hline $\begin{array}{l}\text { Przedsiębiorstwa udzielające } \\
\text { pożyczek ze środków własnych } \\
\text { i współpracujące z bankami }\end{array}$ & 37 & 148 & 132 & 249 \\
\hline
\end{tabular}

Źródło: Działalność przedsiębiorstw pośrednictwa kredytowego w 2014 r., GUS, Warszawa 2015.

Spośród 140 badanych przedsiębiorstw, 62 firmy zajmowały się pośrednictwem kredytowym i udzielaniem pożyczek ze środków własnych - jako jedynym rodzajem działalności, dla 45 podmiotów była to działalność dominująca, z kolei dla 33 przedsiębiorstw - pośrednictwo kredytowe stanowiło działalność uboczną ${ }^{26}$.

Za pośrednictwem firm doradztwa finansowego ZFDF udzielono kredytów hipotecznych o łącznej wartości ponad 3,76 mld zł w II kwartale 2015 r. (o 14\% więcej niż w I kwartale 2015 r.). Świadczy to o znacznym stopniu zaangażowania firm pośrednictwa i doradztwa finansowego na rynku usług finansowych w Polsce (tab. 2).

Doradcy dywersyfikują portfel swoich usług oferując również sprzedaż produktów inwestycyjnych. Obserwując dane dotyczące sprzedaży produktów inwestycyjnych członków ZFDF zauważamy, że łączna wartość sprzedaży tych produktów w I kwartale 2015 r. wyniosła ponad 1,7 mld zł (tab. 3). Zatem firmy doradztwa finansowego zajmują się nie tylko pośrednictwem w sprzedaży kredytów bankowych ale również sprzedażą produktów inwestycyjnych, które wymagają solidnego przygotowania ze strony doradcy finansowego.

\footnotetext{
${ }^{25}$ Działalność przedsiębiorstw pośrednictwa kredytowego w 2014 r., GUS, Warszawa 2015.

${ }^{26}$ Ibidem.
} 
Tabela 2. Wartość wypłaconych kredytów hipotecznych sprzedanych przez członków ZFDF (w mln zł)

\begin{tabular}{|c|l|c|c|c|}
\hline Lp. & Nazwa firmy & IV kwartał 2014 & I kwartał 2015 & II kwartał 2015 \\
\hline \hline 1 & $\begin{array}{l}\text { Open Finance } \\
\text { + Home Broker }\end{array}$ & 1275,00 & 1259,00 & 1352,00 \\
\hline 2 & Expander & 990,15 & 975,78 & 1129,34 \\
\hline 3 & Aspiro & 401,23 & 373,39 & 550,11 \\
\hline 4 & $\begin{array}{l}\text { Notus Doradcy } \\
\text { Finansowi }\end{array}$ & 524,42 & 480,75 & 517,81 \\
\hline 5 & Gold Finance & 191,23 & 175,15 & 183,05 \\
\hline 6 & Doradcy24 & 55,50 & 38,90 & 43,60 \\
\hline Razem & & 3441,53 & 3302,97 & 3775,91 \\
\hline
\end{tabular}

Źródło: Związek Firm Doradztwa Finansowego, http://www.zwiazek-doradcow.org/index.php/ czlonkowie-zfdf [dostęp: 18.02.2016].

Tabela 3. Wartość wypłaconych produktów inwestycyjnych sprzedanych przez członków ZFDF (w mln zł)

\begin{tabular}{|c|l|c|c|c|}
\hline Lp. & Nazwa firmy & IV kwartał 2014 & I kwartał 2015 & II kwartał 2015 \\
\hline \hline 1 & $\begin{array}{l}\text { Open Finance } \\
\text { + Home Broker }\end{array}$ & 1208,00 & 1625,00 & 1262,00 \\
\hline 2 & Expander & 115,62 & 97,31 & 113,6 \\
\hline 3 & Gold Finance & 0,75 & 1,65 & 0,59 \\
\hline Razem & 1324,37 & 1723,96 & 1375,75 \\
\hline
\end{tabular}

Źródło: jak do tab. 2.

Rynek usług doradztwa finansowego obejmuje wiele instytucji doradztwa finansowego, wiele placówek i doradców pracujących w placówkach własnych i partnerskich oraz znaczną wartość sprzedanych usług finansowych. W związku z brakiem regulacji zewnętrznych branży doradców finansowych pojawily się organizacje samoregulujące zrzeszające instytucje doradców finansowych, jak np. Związek Firm Doradztwa Finansowego ${ }^{27}$. Rynek doradztwa finansowego w Polsce jest jednak w fazie inicjalnej głównie z tego względu, że zawód doradcy finansowego wprowadzony został dopiero w 2010 r., ponadto brak jest nadzoru organu państwowego na rynkiem doradztwa finansowego i wymogów licencjonowania doradców finansowych (dobrowolne certyfikacje według Standarów EFFP lub EFPA) oraz nie ma zakazu stosowania określenia doradcy finan-

\footnotetext{
${ }^{27}$ K. Waliszewski, Wspótpraca ..., s. 144.
} 
sowego dla osób fizycznych i podmiotów, które nie spełniają standardu zawodowego (przyjętego w 2013 r.) ${ }^{28}$.

Od 2002 r. działa Polska Izba Pośredników Ubezpieczeniowych i Finansowych (PIPUiF), która funkcjonuje na podstawie przepisów Ustawy $z$ dnia 30 maja 1989 r. o izbach gospodarczych (DzU 1989, nr 35, poz. 195, ze zm.). Izba jako organizacja samorządu gospodarczego zrzeszająca instytucje gospodarcze, współpracuje z ponad 12 tys. pośredników ubezpieczeniowych i finansowych. Ponadto od 2003 r. Polska Izba Pośredników Ubezpieczeniowych i Finansowych została członkiem Europejskiej Federacji Pośredników Ubezpieczeniowych (BIPAR), która powstała w 1937 r. BIPAR ma siedzibę w Brukseli i zrzesza 50 organizacji krajowych, które reprezentują ponad 250 tys. pośredników ubezpieczeniowych. Do istotnych osiągnięć BIPAR należy założenie i bycie członkiem Światowej Federacji Pośredników Ubezpieczeniowych (World Federation of Insurance Intermediaries - WFII) ${ }^{29}$ która zrzesza 100 organizacji z 80 krajów świata. Europejska Federacja Pośredników Ubezpieczeniowych jest uznawana przez Komisję Europejską, a Światowa Federacja Pośredników Ubezpieczeniowych przez OECD, WTO czy IAIS ${ }^{30}$. Celem PIPUiF jest uczestnictwo $\mathrm{w}$ tworzeniu aktów prawnych związanych $\mathrm{z}$ działalnością ubezpieczeniową i finansową, reprezentowanie interesów środowiska, a także współpraca z instytucjami i organizacjami rynku finansowego i ubezpieczeniowego. Ponadto do zadań Izby należy zwiększanie świadomości ubezpieczeniowej i finansowej w społeczeństwie, podnoszenie kwalifikacji zawodowych pośredników oraz etyki zawodowej. Polska Izba Pośredników Ubezpieczeniowych i Finansowych kieruje się zasadami Kodeksu Etyki $i^{31}$. W części trzeciej opracowania skupiono uwagę właśnie na kodeksach etyki - a dokładnie przeanalizowano, które przedsiębiorstwa lub ich związki na rynku doradztwa i pośrednictwa finansowego stosują kodeks dobrych praktyk.

\section{KODEKS ETYKI (DOBRYCH PRAKTYK) NA RYNKU DORADZTWA I POŚREDNICTWA FINANSOWEGO}

Na polskim rynku istnieje m.in. Związek Firm Doradztwa Finansowego ${ }^{32}$, który powstał w 2008 r. i skupia firmy zajmujące się doradztwem i pośrednictwem finansowym. Zawód doradcy, ze względu na dobro i potrzeby klienta,

\footnotetext{
${ }^{28}$ Polski rynek doradztwa finansowego na tle największych rynków europejskich, http://gf24.pl/ polski-rynek-doradztwa-finansowego-na-tle-najwiekszych-rynkow-europejskich/ [dostęp: 25.02.2016].

${ }^{29} \mathrm{http} / / /$ www.bipar.eu/ [dostęp: 01.02.2016].

${ }^{30} \mathrm{http}: / /$ www.posrednicy.org.pl/statut [dostęp: 12.02.2016] .

${ }^{31} \mathrm{http} / / / w w w . p o s r e d n i c y . o r g . p l / k o d e k s-e t y k i$ [dostęp: 01.02.2016].

${ }^{32}$ Ustawa z dnia 23 maja 1991 roku o organizacjach pracodawców, DzU 1991, nr 55, poz. 235 , ze zm.
} 
powinien stać się zawodem godnym zaufania publicznego, dlatego ZFDF wypracował wspólny standard pracy doradców finansowych. Podjęto również uchwałę o działaniu według Kanonu Dobrych Praktyk Rynku Finansowego, który uzyskał rekomendację Komisji Nadzoru Finansowego (KNF), podkreślając tym samym wagę regulacji i ograniczeń, jakie uczestnicy rynku finansowego dobrowolnie nakładają na siebie, z uwzględnieniem mediacji, która umożliwia realizację różnych interesów stron umów zawieranych na rynku finansowym. W 2008 r. KNF zatwierdziła uchwałę nr 99/08 w sprawie rekomendacji stosowania Kanonu Dobrych Praktyk Rynku Finansowego przyjmując jednocześnie rezultat prac instytucji i organizacji rynku finansowego nad Kanonem ${ }^{33}$. Przypisano w nim dużą rolę standardom etycznym jak i jakościowym z naciskiem na opracowywanie i wdrażanie wspólnego standardu raportowania wyników sprzedażowych, jak również stworzenie kompendium wiedzy niezbędnej klientowi w momencie podejmowania decyzji finansowych ${ }^{34}$. KNF oparła powyższe uchwały na art. 11 ust. 1 Ustawy z dnia 21 lipca 2006 r. o nadzorze nad rynkiem finansowym (DzU 2006, nr 157, poz. 1119, ze zm.).

Kanon Dobrych Praktyk Rynku Finansowego ma zapewnić zrównoważony rozwój i bezpieczeństwo rynku, którego podstawą jest etyczny wymiar działań podmiotów finansowych. Kanon wskazuje podstawowe wartości i ideały etyczne, którymi powinny kierować się podmioty finansowe, oraz przy zachowaniu tajemnicy zawodowej i handlowej powinny współdziałać w promowaniu dobrych praktyk rynkowych i ładu korporacyjnego. Wśród wymienionych w $\mathrm{Ka}$ nonie wartości wymienia się następujące zasady: uczciwość, staranność i kompetencje, godność i zaufanie, zasoby i procedury, relacje wewnętrzne, zapobieganie konfliktom interesów, informacje od klientów, ochrona informacji o klientach, informacje dla klientów, profilowanie usług, rzetelna reklama, reklamacje klientów, stosunki wzajemne i uczciwa konkurencja, rozstrzyganie sporów wzajemnych, działania dla rozwoju rynku, stosowanie Kanonu ${ }^{35}$. Istotną inicjatywą jest przyjęcie przez Związek Firm Doradztwa Finansowego i Związek Banków Polskich w 2014 r. Rekomendacji dobrych praktyk dla Doradców kredytowych. Kredyty hipoteczne ${ }^{36}$, co stanowi ważny krok w kierunku usystematyzowania zasad stosowanych przez doradców kredytowych.

${ }^{33}$ Uchwała nr 99/08 Komisji Nadzoru Finansowego z dnia 18 czerwca 2008 roku w sprawie rekomendacji stosowania Kanonu Dobrych Praktyk Rynku Finansowego.

${ }^{34}$ Statut Zwiazku Firm Doradztwa Finansowego, Związek Firm Doradztwa Finansowego, http://www. zwiazek-doradcow.org [dostęp: 01.02.2016].

${ }^{35}$ Kanon Dobrych Praktyk Rynku Finansowego, http://www.zwiazekdora-dcow.org/userfiles/ kanon_dobrych_praktyk.pdf [dostęp: 11.02.2016].

${ }^{36}$ Rekomendacja dobrych praktyk dla Doradców kredytowych. Kredyty hipoteczne, http://www.zwiazek-doradcow.org/userfiles/xpages/files/Rekomendacja_dobrych_praktyk_dla_Doradcow_kredytowych.pdf [dostęp: 20.02.2016]. 
Ponadto istnieje Kodeks Etyki Dla Przedsiębiorców, który jest rekomendowany przez Krajową Izbę Gospodarczą. Kodeks ten został opracowany przez Fundację „Instytut Badań nad Demokracją i Przedsiębiorstwem Prywatnym” na podstawie dokumentów Institute of Business Ethics z Londynu. Kodeks ten reguluje kwestie podstawowych wartości etycznych opartych na uczciwości i rzetelności w działalności gospodarczej. W Kodeksie podkreśla się, że warunkiem koniecznym dla osiągnięcia stabilności przedsiębiorstwa i jego sukcesu jest uczciwość, a największą wartością firmy jest jej dobra reputacja wśród klientów i zaufanie do niej ${ }^{37}$.

W 1999 r. powstała Konferencja Przedsiębiorstw Finansowych (KPF) w Polsce - Związek Pracodawców, która zrzesza kluczowe przedsiębiorstwa z rynku finansowego, są wśród nich: banki, doradcy i pośrednicy finansowi, przedsiębiorstwa pożyczkowe. KPF opracował Zasady Dobrych Praktyk Przedsiębiorstw Zrzeszonych w KPF $w$ Polsce. Kodeks ten reguluje między innymi: zasady dobrych praktyk sprzedaży produktów kredytowych; zasady dobrych praktyk windykacyjnych; zasady dobrych praktyk w biurach informacji gospodarczej; zasady dobrych praktyk funduszy hipotecznych oraz zasady dobrych praktyk pośrednictwa finansowego. W księdze szóstej dotyczącej zasad dobrych praktyk pośrednictwa finansowego oprócz wartości podstawowych jak: odpowiedzialna komunikacja, doskonalenie wiedzy i kompetencji, wiedzy eksperckiej i bezpieczeństwa, informowania klientów i uczciwej konkurencji uregulowano kwestie związane z odpowiedzialnym pośrednictwem finansowym. Ponadto wskazano na stosowanie dobrych praktyk w zakresie informowania klientów, reklamy, uczciwej współpracy i etycznej konkurencji, współpracy pośredników $\mathrm{z}$ instytucjami finansowymi oraz reklamacji klientów ${ }^{38}$. Na straży przestrzegania Zasad Dobrych Praktyk przez zrzeszone przedsiębiorstwa stoi Komisja Etyki powołana w 2005 r. przez $\mathrm{KPF}^{39}$. Kontrola zgodności procedur stosowanych przez przedsiębiorstwo finansowe z Zasadami Dobrych Praktyk odbywa się raz w roku poprzez tzw. audyt wewnętrzny (uregulowany przez dokument Zasad Dobrych Praktyk Przedsiębiorstw Zrzeszonych w KPF $)^{40}$.

KPF przystąpiła do Eurofinas (European Federation of Finance House Associations), która reprezentuje instytucje związane z udzielaniem kredytów konsumenckich na forum europejskim. Eurofinas został powołany w $1963 \mathrm{r}$. natomiast Polska przystąpiła niego w 2006 r. Eurofinans reprezentuje 17 orga-

${ }^{37}$ Kodeks etyki dla przedsiębiorców, http://www.kig.pl/kodeks-etyki-dla-przedsiebiorcow.html [dostęp: 20.02.2016].

${ }^{38}$ Zasady Dobrych Praktyk Przedsiębiorstw Zrzeszonych w Konferencji Przedsiębiorstw Finansowych w Polsce, Konferencja Przedsiębiorstw Finansowych w Polsce, czerwiec 2015, s. 1-51.

${ }^{39}$ Regulamin Pracy Komisji Etyki Konferencji Przedsiębiorstw Finansowych w Polsce - Związu Pracodawców, Konferencja Przedsiębiorstw Finansowych w Polsce, Warszawa, 2014, s. $1-11$.

${ }^{40}$ Zasady..., s. 1-51. 
nizacji członkowskich z 17 państw (w tym m.in. Belgia, Niemcy, Irlandia, Włochy, Portugalia, Szwecja, Wielka Brytania i inne), jest również partnerem instytucji europejskich jak: Parlament Europejski, Komisja Europejska czy Rada $\mathrm{UE}^{41}$. Eurofinas opracowała dokument pt. National codes of conduct for consumer lending opisujący zasady odpowiedzialnego pożyczania, jakimi kierują narodowe organizacje członkowskie, w tym $\mathrm{KPF}^{42}$.

W Polsce funkcjonuje również Związek Niezależnych Doradców Finansowych $(\mathrm{ZNDF})^{43}$, który jest organizacją skupiającą osoby fizyczne i prawne zajmujące się doradztwem i sprzedażą produktów finansowych (w tym głównie produktów kredytowych, inwestycyjnych i ubezpieczeniowych). ZNDF jako stowarzyszenie obliguje swoich członków do przestrzegania Kodeksu Niezależnego Doradcy Finansowego. Wśród zasad ogólnych Kodeksu ZNDF wymieniono: obiektywne doradztwo, standardy kwalifikacji, rzetelność w obsłudze, poufność, postawa wobec innych doradców finansowych, upowszechnianie zasad etyki zawodowej ${ }^{44}$.

Należy wspomnieć również o pozarządowej organizacji European Financial Planning Association (EFPA) posiadającej zaakceptowane przez branżę standardy zawodowe, edukacyjne, egzaminacyjne i etyczne dla doradców i ekspertów planowania finansowego. EFPA działa od 2000 r., a obecnie jest reprezentowana w 12 krajach Unii Europejskiej, takich jak: Austria, Belgia, Czechy, Dania, Hiszpania, Holandia, Francja, Irlandia, Niemcy, Polska, Węgry, Wielka Brytania, Włochy. W Polsce EFPA reprezentowana jest przez Fundację na rzecz Standardów Doradztwa Finansowego, EFPA Polska ${ }^{45}$. EFPA rekomenduje upowszechnianie i stosowanie Europejskiego Kodeksu Etyki. Kodeks Etyki Europejskiego Stowarzyszenia Planowania Finansowego EFPA składa się z zasad przewodnich, które stanowią podstawowe zachowania etyczne doradców finansowych oraz z zasad podstawowych, które określają rekomendacje dla organizacji krajowych $w$ obszarze interpretacji oraz implementacji każdej z zasad przewodnich. Komitet Etyki organizacji krajowej dysponuje prawem zawieszenia lub odebrania certyfikatu EFPA w przypadku naruszenia Kodeksu Etyki. Wśród zasad podstawowych Kodeksu Etyki EFPA wymienia się: orientację na klienta, najwyższe standardy - rzetelności, prawości i uczciwości, niezależność i obiektywizm, kompetencje zawodowe, wymaganej wiedzy w zakresie compliance (czyli aktualnych przepisów, regulacji,

\footnotetext{
${ }^{41}$ Eurofinas, http://www.eurofinas.org/index.php?page=about-us [dostęp: 14.02.2016].

${ }^{42}$ National Codes of Conduct for Consumer Lending, Eurofinas, http://www.eurofinas.org/uploads/documents/reports/CodesConduct.pdf [dostęp: 14.02.2016].

${ }^{43}$ Związek Niezależnych Doradców Finansowych, http://www.zndf.pl/o-zwiazku [dostęp: 14.02.2016].

${ }^{44}$ Kodeks Związu Niezależnych Doradców Finansowych, http://www.zndf.pl/kodeks-zndf [dostęp: 14.02.2016].

${ }^{45}$ EFPA, http://www.efpa.pl/artykuly.php?id=efpaeuropa [dostęp: 14.02.2016].
} 
zasad oraz kodeksów etyki), rzetelną podstawę i uczciwą prezentację, zapobieganie i ujawnianie konfliktów interesów, właściwe wykorzystanie certyfikatów EFPA $^{46}$.

Inną instytucją zrzeszającą doradców i pośredników finansowych jest Europejska Federacja Doradców Finansowych Polska (EFFP Polska), która jest organizacją akredytowaną w ramach FECIF (Fédération Européenne des Conseils et Intermédiares Financiers ) - The European Federation of Financial Advisors and Intermediares (Europejska Federacja Doradców i Pośredników Finansowych $^{47}$ ). EFFP Polska jest organizacją pożytku publicznego (od 2013 r.), która istnieje od 2007 r. działając na rzecz zwiększania bezpieczeństwa finansowego konsumentów oraz upowszechniania wizerunku uczciwego, kierującego się zasadami etycznymi doradcy finansowego. EFFP Polska przeprowadza 3-stopniową certyfikację. Absolwenci otrzymują certyfikaty EFFP, czyli niezależnej europejskiej instytucji certyfikującej Doradców Finansowych, którzy zobowiązani są do przestrzegania Zasad Etycznych European Federation of Financial Professionals $^{48}$.

Warto w tym miejscu zauważyć obowiązek przestrzegania w Polsce od kwietnia 2010 r. unijnej dyrektywy MiFID (Markets in Financial Instruments Directive, 2004/39/EC ${ }^{49}$ ) dotyczącej rynków instrumentów finansowych, która z założenia ma chronić klientów, m.in.: towarzystw funduszy inwestycyjnych, banków, domów maklerskich oraz pośredników finansowych. Zgodnie z zaleceniami dyrektywy MiFID instytucje finansowe podczas sprzedaży swoich produktów mają obowiązek rzetelnego informowania klientów o ryzyku. Według MiFID podmioty, które oferują usługi inwestycyjne zobowiązane są działać w sposób uczciwy, rzetelny i profesjonalny, zgodnie z najlepiej pojętymi interesami klientów. Informacje dotyczące instrumentów finansowych przekazywane klientom powinny być zrozumiałe, przejrzyste i przede wszystkim dostosowane do profilu klienta, jak również powinny obejmować dane o ryzyku związanym z danym instrumentem ${ }^{50}$. W 2014 r. wprowadzono nową dyrektywę MiFID II (dyrektywa 2014/17/UE), która reguluje chociażby kwestie wynagradzania za usługi doradztwa finansowego (w celu ograniczenia sugerowania klientom pro-

\footnotetext{
${ }^{46}$ EFPA Polska, http://www.efpa.pl/artykuly3.php?id=kodeksetyki\&men=efpapolska [dostęp: 14.02.2016].

${ }^{47}$ W 2007 r. powstało stowarzyszenie FECIF Polska z siedzibą w Poznaniu, działające jako oddział Europejskiej Federacji Doradców I Pośredników Finansowych FECIF.

${ }^{48}$ EFFP-European Federation of Financial Professionals, http://www.effp.pl/page/28.html [dostęp: 14.02.2016].

${ }^{49}$ MiFID tworzą następujące akty prawne: dyrektywa 2004/39/WE Parlamentu Europejskiego i Rady z 21 kwietnia 2004 w sprawie rynków instrumentów finansowych oraz dyrektywa nr 2006/31/WE Parlamentu Europejskiego i Rady z dnia 5 kwietnia 2006, która zmienia dyrektywę 2004/39/WE w sprawie niektórych terminów a także dyrektywa Komisji 2006/73/WE z 10 sierpnia 2006 roku, która jest aktem wykonawczym do dyrektywy 2004/39/WE.

${ }^{50}$ https://www.bgk.com.pl [dostęp: 19.02.2016].
} 
duktów o wysokich prowizjach dla doradców), ponadto zwiększa stabilność i przejrzystość rynku finansowego oraz wprowadza ankietowanie klienta pod kątem konstrukcji produktu i ryzyka ${ }^{51}$.

\section{PODSUMOWANIE}

Etyczne postępowanie uczestników rynku finansowego jest podstawą zrównoważonego rozwoju i bezpieczeństwa tego rynku. Znaczenie stosowania zasad dobrych praktyk jest istotne $\mathrm{w}$ kontekście zwiększania przejrzystości rynku i budowania wzajemnego zaufania pomiędzy jego uczestnikami. Rynek doradztwa i pośrednictwa finansowego to ważny element rynku finansowego jednak wymagający regulacji. Stąd oparcie zasad funkcjonowania rynku doradztwa i pośrednictwa finansowego na etycznych wartościach ujętych w kodeksach etyki (kanonach dobrych praktyk) jest niezbędnym warunkiem dalszego rozwoju tego rynku. W opracowaniu przedstawiono instytucje doradztwa i pośrednictwa finansowego, które przyjęły kodeks etyki. Ponadto wskazano na istotne znaczenie postępowania instytucji pośrednictwa i doradztwa finansowego na rynku finansowym zgodnie z zasadami etyki. Tym samym zrealizowano cel niniejszego opracowania. Zasady dobrych praktyk powinny być aktualną i wymaganą rekomendacją wobec codziennych praktyk biznesowych, szczególnie wśród doradców i pośredników finansowych. Podsumowując ustalono, że postępowanie zgodnie $\mathrm{z}$ zasadami etyki na rynku usług i doradztwa finansowego jest niezbędnym warunkiem rozwoju i stabilności tego rynku, co stanowiło główny problem badawczy opracowania.

\section{BIBLIOGRAFIA}

Barembruch A., Znaczenie doradztwa kredytowego w sprzedaży kredytów, [w:] E. Gostomski, M. Penczar, B. Lepczyński, A. Barembruch, Pośrednictwo kredytowe w Polsce. Podręcznik dla praktyków, CeDeWu, Warszawa 2006.

Czechowska I. D., Kodyfikacja standardów etycznych ze szczególnym uwzględnieniem kodeksów etycznych banków, „Bezpieczny Bank” 2015, nr 1(58).

Działalność przedsiębiorstw pośrednictwa kredytowego w 2014 r., GUS, Warszawa 2015.

Eurofinas, http://www.eurofinas.org/index.php?page=about-us.

EFPA Polska, http://www.efpa.pl/artykuly3.php?id=kode-ksetyki\&men=efpapolska.

EFPA, http://www.efpa.pl/artykuly.php?id=efpaeuropa.

EFFP-European Federation of Financial Professionals, http://www.effp.pl/page/28.html.

Freeman E., Strategic Management:A Stakeholder Approach, Pitman, Boston 1984.

Gasparski W., Wyktady z etyki biznesu, WSPiZ, Warszawa 2007.

\footnotetext{
${ }^{51}$ https://www.kpf.pl [dostęp: 26.02.2016]
} 
Gasparski W., Europejskie standardy etyki biznesu, http://www.ipsir.uw.edu.pl/UserFiles/File/ Katedra_Socjologii_Norm/TEKSTY/WGasparskiEuropStandEtykiBiznesu.pdf.

Kanon Dobrych Praktyk Rynku Finansowego, http://www.zwia-zekdoradcow.org/userfiles/kanon_dobrych_praktyk.pdf.

Klimek J., Etyka biznesu, Teoretyczne zatożenia, praktyka zastosowań, Difin, Warszawa 2014.

Kodeks etyki dla przedsiębiorców, http://www.kig.pl/kodeks-etyki-dla-przedsiebiorcow.html.

Kodeks Związu Niezależnych Doradców Finansowych, http://www.zndf.pl/kodeks-zndf.

Lipiński C., Etyka w bankowości - dylematy pracownika bankowego, „Annales. Etyka w Życiu Gospodarczym" 2008, vol. 11, nr 2.

National Codes of Conduct for Consumer Lending, Eurofinas, http://www.eurofinas.org/uploads/documents/reports/CodesConduct.pdf

Polski rynek doradztwa finansowego na tle największych rynków europejskich, http://gf24.pl/polski-rynek-doradztwa-finansowego-na-tle-najwiekszych-rynkow-europejskich/.

Regulamin Pracy Komisji Etyki Konferencji Przedsiębiorstw Finansowych w Polsce-Zwiazku Pracodawców, Konferencja Przedsiębiorstw Finansowych w Polsce, Warszawa 2014.

Rekomendacja dobrych praktyk dla Doradców kredytowych. Kredyty hipoteczne, http://www.zwiazekdoradcow.org/userfiles/xpages/fi-les/Rekomendacja_dobrych_praktyk_ dla_Doradcow_kredytowych.pdf.

Rynek doradztwa finansowego w Polsce 2012, Raport Bankier.pl i „Wprost”, http://www.bankier.pl/ static/att/90000/2492942_Ra-portRynekDoradztwaFinansowegowPolsce2012.pdf.

Steinmann H., Schreyogg G., Zarzadzanie: podstawy kierowania przedsiębiorstwem. Koncepcje, funkcje, przyktady, Oficyna Wydawnicza Politechniki Wrocławskiej, Wrocław 2001.

Strzelecki A., Moda na etykę. Współczesna refleksja etyczna $w$ biznesie i fenomen jej popularności, „Studia i Materiały” 2005, nr 1.

Statut Zwiazku Firm Doradztwa Finansowego, Związek Firm Doradztwa Finansowego, http://www. zwiazek-doradcow.org.

The Global Sullivan Principles of Social Responsibility, http://www.thesullivanfoundation.org/.

Ustawa z dnia 23 maja 1991 r. o organizacjach pracodawców, DzU 1991, nr 55, poz. 235, ze zm.

Ustawa z dnia 30 maja 1989 r. o izbach gospodarczych, DzU 1989, nr 35, poz. 195, ze zm.

Uchwała nr 99/08 Komisji Nadzoru Finansowego z dnia 18 czerwca 2008 r. w sprawie rekomendacji stosowania Kanonu Dobrych Praktyk Rynku Finansowego.

Waliszewski K., Nadzór i licencjonowanie doradców finansowych i pośredników kredytowych a stabilność i bezpieczeństwo polskiego systemu bankowego, [w:] A. Janc (red.), Banki i system bankowy w obliczu kryzysów finansowych, ,Zeszyt Naukowy Uniwersytetu Ekonomicznego w Poznaniu" 2010, nr 155.

Waliszewski K., Planowanie finansów osobistych (zarzązanie finansami osobistymi) z udziałem doradców finansowych - znaczenie dla gospodarstw domowych i gospodarki, „Problemy Zarządzania” 2014, vol. 12, nr 4(48), t. 1: Współczesne wyzwania w bankowości i finansach.

Waliszewski K, Wspólpraca banków i doradców finansowych w Polsce - szanse i zagrożenia dla banków i sektora bankowego, „Bezpieczny Bank” 2010, nr 3(42).

Wiśniewska M., Kodeks dobrej praktyki bankowej jako zbiór norm etycznych $i$ ważny element kultury bankowego środowiska zawodowego. Etyka biznesu i etyka zawodowa, „Annales. Etyka w Życiu Gospodarczym" 2003, vol. 6.

Zasady Dobrych Praktyk Przedsiębiorstw Zrzeszonych w Konferencji Przedsiębiorstw Finansowych w Polsce, Konferencja Przedsiębiorstw Finansowych w Polsce, czerwiec 2015.

Związek Firm Doradztwa Finansowego, http://www.zwiazek-doradcow.org/index.php/czlonkowie-zfdf.

Związek Niezależnych Doradców Finansowych, http://www.zndf.pl/o-zwiazku.

http://www.cauxroundtable.org/index.cfm?\&menuid=8.

http://www.globalcompact.org.pl/pol/Global-Compact/10-Zasad-GC.

http://www.posrednicy.org.pl/statut. 
http://www.bipar.eu/.

http://www.posrednicy.org.pl/kodeks-etyki.

https://www.bgk.com.pl.

https://www.kpf.pl/pliki/komen-tarz_eksperta/odpowiedzialny_kredyt.pdf.

\title{
ETHICS ON THE MARKET OF ADVISORY SERVICES AND FINANCIAL INTERMEDIATION
}

\begin{abstract}
The purpose of this paper is to present advisory institutions and financial intermediaries that act according to the code of ethics and an indication of the importance of these institutions to the financial services market. The research problem is to determine the importance of following the rules of ethics advisory market and financial intermediation. To achieve this objective were used: the method of the literature analysis, the data presented by the organizations, financial advisors and analysis of legal acts. The paper consists of three parts: the first focuses on the importance of ethics for the financial services market, the second shows the counseling institutions and financial intermediaries on the financial services market, while the third part presents the codes of ethics and the institutions applying them on the advisory market and financial intermediation. It is worth noting that the market for advisory and financial intermediation in Poland requires higher standards of services provided also by increasing the role of ethical advice and financial intermediation.
\end{abstract}

Keywords: financial advising, financial intermediation, code of ethics. 